\title{
Management of blood lipid profile and oxidative status in Holstein and Simmental dairy cows during lactation
}

\author{
Dejan Obućinski1, Dragan Soleša ${ }^{1}$, Denis Kučević², Radivoj Prodanović1, Mirela \\ Tomaš Simin², Dragana Ljubojević Pelić3, Olivera Đuragićc ${ }^{4}$ Nikola Puvača ${ }^{1 *}$
}

\begin{abstract}
'University Business Academy, Faculty of Economics and Engineering Management, Department of Engineering Management in Biotechnology, Cvećarska 2, 21000 Novi Sad, Serbia ${ }^{2}$ University of Novi Sad, Faculty of Agriculture, Trg Dositeja Obradovića 8, 21000 Novi Sad, Serbia ${ }^{3}$ Scientific Institute of Veterinary Medicine "Novi Sad", Rumenački put 20, 21000 Novi Sad, Serbia

${ }^{4}$ Scientific Institute for Food Technology, University of Novi Sad, Bulevar cara Lazara 1, 21000 Novi Sad, Serbia

${ }^{*}$ Corresponding author: E-mail: nikola.puvaca@fimek.edu.rs
\end{abstract}

\section{Abstract}

Managing and determination of the blood lipid profile and oxidative status are useful tool to show the influence of foreign chemical substances on production of dairy cows. Investigation of various biomarkers of oxidative stress related to various problems in the production dairy cows presents a very important issue. The aim of this research was to investigate different biological markers in two different breeds of dairy cows - the Holstein Friesian and the Simmental, during different stages of lactation. The total of 60 Holstein Friesian and Simmental cows were divided into two treatments (HF and S) which was further divided into three groups each, respectively. Lactating groups of each cow breed was divided into three stages at early lactation of 32-75 days (HF1 and S1), peak lactation of 80-165 days (HF2 and S2) and low lactation of 175 days onward (HF3 and S3). During the research the total milk production and the percentage of milk fat and protein were determined. Blood samples were collected from jugular vein of each cow, the serum was harvested without anticoagulant and stored at $-20^{\circ} \mathrm{C}$ in small aliquots till further analysis. Serum was then analyzed for triglyceride, cholesterol, HDL, LDL, AST, ALT, GGT, the total antioxidant status (TAS), the total oxidant status (TOS), MDA, SOD, catalase and paraoxonase (PON1). Significantly ( $\mathrm{P}<0.05)$ higher values of cholesterol, TOS and SOD at peak lactation stage was observed in all cows. A gradual decline from early lactation to low lactation was observed in the values of triglycerides and ALT, while MDA gradually increased from the same stage in all cows. The values of LDL and catalase showed an irregular pattern of variations in various lactation stages among all groups. The Holstein Friesian breed showed significantly higher values of ALT and PON1, while values of HDL, TAS and TOS were the lowest in Simmental group $(\mathrm{P}<0.05)$. By measuring the signs of oxidative stress, it was concluded that metabolic efforts of cows during the peak of lactation affected the investigated parameters. Disturbance in feed intake and rise in metabolic processes lift up oxidative stress in cows, especially during the peak of lactation, which might be determined by monitoring blood alterations. Results of our study indicated that the Holstein Friesian breed was under higher oxidative stress during different lactation stages compared to Simmental dairy cows.

Key words: management, cows, lactation, milk production, stress, biomarkers 


\section{Introduction}

Over the last few decades, considerable changes have occurred in the European dairy cattle production. Crossings with the upgrading method have changed the genetic structure of the most combined breeds in the European countries (Obućinski et al., 2019). In breeding, the most frequently used breed has been the intensive dairy Holstein Friesian (HF) breed (Nemes et al., 2016). The term "biomarker" was used for the first time almost 40 years ago. Biomarker is an intentionally measured feature, estimated as an indicator of ordinary biological processes, pathogenic processes, or pharmacologic responses to a therapeutic interference. Biomarkers can be used to show an exposure to the consequence of unknown chemical substances that may be present in our vicinity.

The biological health markers of animals significantly depend on the modifications in components of biochemical and hematological processes (Hassan et al., 2012). The biochemistry of blood is estimated in order to evaluate the health status of cows. This estimation of blood biochemistry is required to identify numerous pathological, physiological and metabolic problems of dairy animals (Park et al., 2010; Koenyves et al., 2017).

Cholesterol is actually a lipid. It is found in the bloodstream and considered as essential to living organisms (Puvača et al., 2016). The function of cholesterol is to build cell membranes and to produce different hormones essential for proper body functions such as estrogen, progesterone and aldosterone (Ahmad et al., 2004). By assessing the parameters such as the total cholesterol, HDL (High density lipoprotein), LDL (Low density lipoprotein) and triglycerides (TG), variations in lipid metabolism occurring in lactating cows could be better understood (Kurpińska et al., 2015). Aspartate transaminase (AST), Alanine transaminase (ALT) and Gamma-glutamyltransferase (GGT) are serum enzymes commonly found in the liver tissues and are considered as biological health markers in case of hepatic disorders and other health issues (Boonprong et al., 2007; Lim et al., 2007). The damaged tissues liberate intracellular enzymes and cause pathological alterations in various tissues resulting in increased concentrations of serum enzymes.

The determination of serum enzymes performance and other parameters is helpful for the diagnosis and understanding of dairy cows' health issues (Elazab, 2015). Researchers are enthusiastic in discovering the biomarkers of oxidative stress as a contributory mediator of the expansion of different health issues in dairy cows. By definition, oxidative stress is a phenomenon of cellular degradation as a result of boosted oxidant release in animal body cells due to the release of free radicals. This condition of chemical stress arises as the release of free radicals within the body cells goes beyond its ability to neutralize and remove those (Popović et al., 2018).

In recent studies, veterinarians have focused onto finding out various antioxidants in animals for remedial intention (Sharma et al., 2011). As there are many biochemical markers that reflect the stress caused by oxidation, while there are several diagnostic procedures being used to evaluate the total antioxidant status (TAS) since it is difficult to assess each antioxidant constituent independently, as well as their relations to other serum components (Castillo et al., 2006). Malondialdehyde (MDA) is preferred as the best indicator of reactive oxygen species and a detector of free oxygen radicals released during abnormal functioning of different tissues (Subdhi et al., 2001). The main function of this enzyme (SOD) is to split the superoxide radical into $\mathrm{O}_{2}$ and $\mathrm{H}_{2} \mathrm{O}_{2}$ (Liu et al., 2012). Catalase is recurrently utilized by cells to quickly catalyze the reaction of $\mathrm{H}_{2} \mathrm{O}_{2}$ to break into less-reactive oxygen gas and water. Paraoxonase (PON1) acts as an antioxidant molecule with the ability to eliminate the oxidized lipids, both on HDL and LDL as well. In this way, it participates in antioxidant mechanisms.

Measuring serum PON1 activity of dairy cattle during different lactation stages could be a useful diagnostic tool helping to obtain better health assessment during high milk production (Kulka et al., 2016). It is factual to acquire information concerning dairy animals' metabolic and health state by serum biochemical analyses as an investigative practice to contrast the values of animals having a detrimental health 
status with the standard values of animals in good physical condition (Jezek et al., 2006). Celi and Gabai (2015) encouraged other scientists to recognize biomarkers of protein oxidation used in veterinary medicine in order to understand role of oxidative stress (Puvača et al., 2018) that lead to decline in animal welfare and production (Obućinski et al., 2019).

On the basis of the previously presented, the aim of this research is to investigate different biological markers in two breeds of dairy cows the Holstein Friesian and the Simmental, during different stages of milk production.

\section{Materials and methods}

The study was carried out by selecting the total of 60 cows belonging to the breeds Holstein Friesian and Simmental, at the age between three and seven years, maintained under production condition at the dairy cattle farm in Paljuvi, municipality Valjevo, Serbia. Animals selected for this research were vaccinated and healthy.

The selected Holstein Friesian and Simmental cows were divided into two equal experimental treatments of 30 cows each (HF and S), respectively. Further, each treatment was divided into three groups of each cow breed, which was divided into three lactation stages as follows: the early lactation of 32-75 days (HF1 and $\mathrm{S} 1$ ); the peak lactation of 80-165 days (HF2 and S2) and the low lactation of 175 days onward (HF3 and S3). Each group consisted of 10 cows, meaning in total of 30 cows per one treatment in three replicates.

The dietary rations given to cows during lactating consisted of clover mixture of alfalfa and barley and ad-libitum. In addition, cows were also fed $4 \mathrm{~kg}$ per day of concentrate containing barley grain (35\%), wheat bran (30\%), maize (17\%), soybean meal ( $25 \%)$, salt, vitamins, and minerals (3\%). The feeding schedule consisted of the energy requirement for the lactating cows.

The total milk production and the contents of milk fat and proteins were determined.

Blood samples were collected aseptically from jugular vein from each cow at different stages of lactation in the morning, under the supervision of a veterinarian engaged for monitoring animal welfare during this research. After centrifugation of blood samples for 15 minutes, the serum was collected without anticoagulant and stored at $-20^{\circ} \mathrm{C}$ in small aliquots till further analysis.

The blood serum tube with samples was defrosted and then kept at room temperature prior to analysis. After complete defrosting, the subsequent biological health markers such as Triglycerides (TG, mg/dL), Cholesterol (Chol, mg/ $\mathrm{dL}$ ), Cholesterol-HDL (HDL-Chol, mg/dL), Low Density Lipoprotein (LDL-Chol, mg/dL) regarding to blood lipid profile and Aspartate Transaminase (AST, U/L), Alanine Transaminase (ALT, U/L), Gamma-glutamyl transferase (GGT, U/L), Total Antioxidant Status (TAS, mmol trolox Equiv./L), Total Oxidant Status (TOS, $\mu \mathrm{mol} \mathrm{H}_{2} \mathrm{O}_{2}$ Equiv./L), Malondialdehyde (MDA, $\mathrm{mmol} / \mathrm{mL}$ ), Superoxide Dismutase (SOD, $\mu / \mathrm{mL}$ ), Catalase Activity (Cat, $\mathrm{KU} / \mathrm{L}$ ), Paraoxonase-1 (PON1; U/min/mL) regarding to blood oxidative status were examined, as previously described in detail by Puvača et al. (2016), Kostadinović et al. (2016) and Popović et al. (2017).

The data were statistically analysed by using a two-way analysis of variance techniques for the determination of difference between the investigated breed groups at various stages by using the STATISTICA 13 software. The means for significance between different stages of lactation were determined by Tukey post-hoc test and $\mathrm{P}<0.05$ were taken as statistical significance.

\section{Results and discussion}

The most important results in terms of milk yield, milk fat percentage and milk protein percentage are showed in Table 1.

The results showed in Table 1 present a statistically significant $(P<0.05)$ difference in the milk yield between the Simmental and the Holstein Friesian cows (6027 and 7567 kg). Statistically significant $(\mathrm{P}<0.05)$ difference can also be seen regarding the average milk fat percentage for total lactation period where the Simmental breed showed a higher milk fat content of $4.79 \%$ compared to the Holstein Friesian breed (4.34 \%). On the opposite, the average milk protein content 
TABLE 1. The total milk yield, milk fat percentage and milk protein percentage

\begin{tabular}{l|l|r|r|r}
\hline Cow breed & $\mathbf{n}$ & Milk yield, kg & Milk fat, \% & Milk protein, \% \\
\hline Simmental (S) & 30 & 6027 & 4.79 & 3.13 \\
\hline Holstein Friesian (HF) & 30 & 7567 & 4.34 & 3.39 \\
\hline Pooled standard error & & 717 & 0.23 & 0.11 \\
\hline
\end{tabular}

Differences with significances

\begin{tabular}{l|r|r|r}
\hline $\mathrm{S}-\mathrm{HF}$ & $-1.54^{*}$ & $0.45^{*}$ & $0.26^{*}$ \\
\hline
\end{tabular}

* - significant difference $P<0.05$

was higher in the Holstein Friesian breed at the same statistical difference $(P<0.05)$, which was opposite to the negative correlation between the fat and protein content. Results from our study is in agreement with the research of Nemes et al. (2016).

Results presented in Table 2 show numerical differences between different lactation periods and between HF and S breeds, but without any statistical significant $(P>0.05)$ differences in total regarding the blood triglycerides levels. All cows showed significantly high cholesterol concentrations at the second stage (HF2 and S2) in comparison to the other two lactation stages. The overall significant $(P<0.05)$ differences were recorded in blood cholesterol levels where the HF breed showed a higher overall cholesterol (47.07 mg/dL) concentration compared to the $\mathrm{S}$ breed $(44.93 \mathrm{mg} / \mathrm{dL})$. The cholesterol values at HF3 and S3 stage decreased and were found nearly similar to each other in both cows breed. Ling et al. (2003) also observed similar results to ours where the cholesterol level was the lowest in the early lactation and then increased gradually during the lactation. The increase in the cholesterol concentration with the progression of lactation was a physiological modification to fulfill the requirements of the milking (Hagawane et al., 2009). In the study of Piccione et al. (2012) the total cholesterol and triglyceride were found to be considerably elevated and encouraged by the biological status throughout the mid lactation period. Our results of high cholesterol concentration at the mid lactation stage coincided with the study of Chalmeh et al. (2015) and Jóźwik et al. (2012). The probable reason for such increase in cholesterol levels might be the high demands for the regulatory mechanisms involved in all the processes of milk synthesis (Krajnicakova et al., 2003). Because of this, typical lipid metabolism changes in the gestation and the lactation period in many cows. Results of our research showed no significant differences $(\mathrm{P}>0.05)$ between $\mathrm{HF}$ and $\mathrm{S}$ cows breed regarding blood HDL and LDL cholesterol concentration.

TABLE 2. Triglycerides, cholesterol, HDL and LDL blood lipid profile

\begin{tabular}{|c|c|c|c|c|c|c|}
\hline & \multicolumn{3}{|c|}{ Holstein Friesian (HF) } & \multicolumn{3}{|r|}{ Simmental (S) } \\
\hline & HF1 & HF2 & HF3 & S1 & S2 & S3 \\
\hline \multirow{2}{*}{ TG } & $86.40 \pm 1.07$ & $92.60 \pm 1.27$ & $78.50 \pm 0.37$ & $109.30 \pm 1.58$ & $79.20 \pm 0.87$ & $59.90 \pm 0.78$ \\
\hline & \multicolumn{3}{|c|}{$85.83 \pm 1.2$} & \multicolumn{3}{|c|}{$82.80 \pm 3.83$} \\
\hline \multirow{2}{*}{ Chol } & $50.40 \pm 0.81$ & $52.70 \pm 1.08$ & $38.10 \pm 0.57$ & $43.10 \pm 0.81$ & $52.00 \pm 0.94$ & $39.70 \pm 0.84$ \\
\hline & \multicolumn{3}{|c|}{$47.07 \pm 1.28^{*}$} & \multicolumn{3}{|c|}{$44.93 \pm 1.08$} \\
\hline \multirow{2}{*}{ HDL } & $21.80 \pm 1.01$ & $34.80 \pm 0.44$ & $24.70 \pm 0.84$ & $22.40 \pm 0.75$ & $35.40 \pm 0.92$ & $28.15 \pm 0.55$ \\
\hline & \multicolumn{3}{|c|}{$27.10 \pm 1.13$} & \multicolumn{3}{|c|}{$28.65 \pm 1.07$} \\
\hline \multirow{2}{*}{ LDL } & $30.30 \pm 0.87$ & $25.90 \pm 0.38$ & $19.00 \pm 0.39$ & $23.04 \pm 0.80$ & $20.97 \pm 0.80$ & $28.55 \pm 0.91$ \\
\hline & \multicolumn{3}{|c|}{$25.07 \pm 0.92$} & \multicolumn{3}{|c|}{$24.19 \pm 0.76$} \\
\hline
\end{tabular}

* - significant difference P<0.05; Triglycerides (TG, mg/dL), Cholesterol (Chol, mg/dL), Cholesterol-HDL (HDL-Chol, mg/dL), Low Density Lipoprotein (LDL-Chol, mg/dL) 
The concentration of HDL was found insignificant in all lactating cows. However, HDL was lower at the early lactation stage and reached its maximum value at the mid lactation stage, while the values decreased again at the late stage of lactation. The gradual decline in serum LDL on the one hand, and the increase in HDL on the other hand showed healthy outcomes at the peak lactation stage in all cows, since HDL participates in the reverse transportation of cholesterol preventing thereby health disorders as arteriosclerosis and coronary artery problems as described by Barter and Rye (1996) and Stein and Stein (1999). These free cholesterol molecules are then transported into the liver via endothelial macrophages and excreted into the bile in order to prevent the development of plagues of arteriosclerosis. Further, HDL participates also directly or indirectly in the prevention of inflammations because of having antithrombotic abilities that reduce formation of blood clots (Barter, 2004; Davidson and Toth, 2007). On contrary, LDL plays a reverse role and is found responsible for plaques development of arteriosclerosis (Gardener et al., 2009). The Simmental breed might be at a high risk of inflammation, arteriosclerosis and coronary artery diseases because of increase in LDL levels throughout the lactation period.

Liver enzymes are very good biomarkers of metabolic changes in cows during the milk production. AST concentration increased from the lactation stage one to the lactation stage three in both breeds. In our research there were no statistically significant $(P>0.05)$ differences in the overall AST levels. Liu et al. (2012) reported AST activities minimum at the 5-7 weeks of lactation and a significant increase in 8-9 weeks of lactation in Holstein cows. A close relationship of varying AST values and hepatic functions, skeletal muscle and cardiac activities of cows have been presented. Determination of AST values might be helpful for finding and diagnosing hepatic disorders (Sattler and Furll, 2004). The higher values of AST reveal that postpartum cows are under physiological stress according to research of Mohamed (2014).

In contrast to AST, the concentration of ALT significantly reduced from the lactation stage one till the lactation stage three, but also without any reordered overall statistical significance $(P>0.05)$.
GGT concentration was significantly high at the lactation stage one (HF1 and S) and decreased significantly $(\mathrm{P}<0.05)$ throughout the lactation period. Milinković-Tur et al. (2005) and Ray et al. (2008) described the importance of aminotransferase in plasma performing catalytic activity in protein and carbohydrates metabolisms. Thus, any alterations in the activities of these serum enzymes become responsible for the cell damage (Lai et al., 2007). High yielding dairy cows at the early lactating stages mobilize the body fat and the occurrence of fat reserves can cause the grievance in the normal hepatic performance (Milinković-Tur et al., 2005). Accordingly, the energy balance becomes negative by the body's physical utilization, which could result in the mobilization of body fat and liver injury and the variation of liver cell permeability causing further variable degrees of increase in enzymes concentrations.

In our research and from results presented in Table 3, TAS concentration was not found to be statistically significant $(P>0.05)$ and was low at the first and the third lactation stage. Increase in serum TAS concentration was observed from HF1 and S1 to HF2 and S2 stage, but decreased at the lactation stages HF3 and S3. HF breed showed higher mean values of serum TAS in lactation phase when compared to the $\mathrm{S}$ breed, but without statistically significant differences $(P>0.05)$. Pedernera et al. (2010) found low antioxidant concentration in the first 14 days of lactation in cows grouped on the basis of different nutrition. Goff and Stabel, (1990) explained that higher amounts of antioxidants are used in the production of colostrum and Pedernera et al. (2010) related this low TAS concentrations to the production of free radicals and involvement of antioxidants in homeorhetic processes normally occurring during the early lactation. Castillo et al. (2006) found no difference in TAS concentration between the early and the late lactating cows, but similarly to our results significant differences were found in the mid lactation stage.

TOS, MDA, SOD and Cat in our research did not show any large differences between breeds, only with slightly higher concentration of TOS and SOD during the peak of lactation (HF2 and S2). Statistically significant differences in regarding this values was not present $(P>0.05)$. Different factors are in- 
TABLE 3. Biochemical, enzymatic and oxidative blood status of lactation cows

\begin{tabular}{|c|c|c|c|c|c|c|}
\hline & \multicolumn{3}{|c|}{ Holstein Friesian (HF) } & \multicolumn{3}{|r|}{ Simmental (S) } \\
\hline & HF1 & HF2 & HF3 & S1 & S2 & S3 \\
\hline \multirow{2}{*}{ AST } & $8.38 \pm 0.14$ & $16.53 \pm 0.44$ & $18.97 \pm 0.13$ & $8.19 \pm 0.11$ & $15.88 \pm 0.35$ & $18.95 \pm 0.15$ \\
\hline & \multicolumn{3}{|c|}{$14.63 \pm 0.85$} & & $14.34 \pm 0.85$ & \\
\hline \multirow{2}{*}{ ALT } & $57.10 \pm 0.62$ & $45.40 \pm 0.72$ & $42.50 \pm 0.37$ & $57.80 \pm 0.65$ & $44.60 \pm 0.64$ & $42.70 \pm 0.45$ \\
\hline & \multicolumn{3}{|c|}{$48.33 \pm 1.22$} & & $48.37 \pm 1.29$ & \\
\hline \multirow{2}{*}{ GGT } & $24.80 \pm 0.53$ & $18.20 \pm 1.26$ & $15.10 \pm 0.35$ & $24.90 \pm 0.38$ & $16.60 \pm 0.52$ & $15.10 \pm 0.31$ \\
\hline & \multicolumn{3}{|c|}{$19.37 \pm 0.88^{*}$} & & $18.87 \pm 0.83$ & \\
\hline \multirow{2}{*}{ TAS } & $2.51 \pm 0.13$ & $3.59 \pm 0.08$ & $2.21 \pm 0.08$ & $2.08 \pm 0.13$ & $3.09 \pm 0.08$ & $1.84 \pm 0.04$ \\
\hline & \multicolumn{3}{|c|}{$2.77 \pm 0.12$} & & $2.34 \pm 0.11$ & \\
\hline \multirow{2}{*}{ TOS } & $2.39 \pm 0.06$ & $3.67 \pm 0.04$ & $2.17 \pm 0.05$ & $1.99 \pm 0.07$ & $2.64 \pm 0.05$ & $1.69 \pm 0.05$ \\
\hline & \multicolumn{3}{|c|}{$2.74 \pm 0.13^{*}$} & & $2.11 \pm 0.08$ & \\
\hline \multirow{2}{*}{ MDA } & $1.34 \pm 0.03$ & $1.84 \pm 0.05$ & $2.52 \pm 0.05$ & $1.05 \pm 0.08$ & $2.46 \pm 0.09$ & $2.21 \pm 0.10$ \\
\hline & \multicolumn{3}{|c|}{$1.90 \pm 0.09$} & & $1.91 \pm 0.12$ & \\
\hline \multirow{2}{*}{ SOD } & $1.36 \pm 0.04$ & $3.07 \pm 0.09$ & $2.16 \pm 0.08$ & $1.64 \pm 0.08$ & $2.65 \pm 0.05$ & $2.10 \pm 0.11$ \\
\hline & \multicolumn{3}{|c|}{$2.20 \pm 0.14$} & & $2.13 \pm 0.09$ & \\
\hline \multirow{2}{*}{ Cat } & $1.78 \pm 0.02$ & $2.72 \pm 0.04$ & $1.75 \pm 0.06$ & $2.54 \pm 0.07$ & $1.21 \pm 0.05$ & $2.47 \pm 0.05$ \\
\hline & \multicolumn{3}{|c|}{$2.08 \pm 0.09$} & & $2.07 \pm 0.12$ & \\
\hline \multirow{2}{*}{ PON1 } & $141.00 \pm 1.00$ & $161.50 \pm 0.72$ & $144.30 \pm 1.04$ & $157.60 \pm 1.29$ & $174.70 \pm 1.04$ & $165.50 \pm 1.23$ \\
\hline & \multicolumn{3}{|c|}{$148.93 \pm 1.75$} & & $165.93 \pm 1.46^{*}$ & \\
\hline
\end{tabular}

* - significant difference P<0.05; Aspartate Transaminase (AST, U/L), Alanine Transaminase (ALT, U/L), Gamma-glutamyl transferase (GGT, U/L), Total Antioxidant Status (TAS, mmol trolox Equiv./L), Total Oxidant Status (TOS, $\mu$ mol H2O2 Equiv./L), Malondialdehyde (MDA, mmol/mL), Superoxide Dismutase (SOD, $\mu / \mathrm{mL})$, Catalase Activity (Cat, KU/L), Paraoxonase-1 (PON1; U/min/ $\mathrm{mL})$

volved to stimulate a chain reaction of lipid peroxidation usually occur at low level in all tissues and elevated in various physiological and pathological situations in which are chances of high oxidative stress. Normally, energy required during lactation is more than the actual need. So, high oxidative stress is expected due to high ingestion and consumption of oxygen during lactation because most of the high milk yielding dairy cows is not able to utilize enough dietary energy resulting in negative energy balance (Upreti et al., 2002). MDA values vary species to species and have link with adaptation of each organism depending upon oxygen consumption and neutralization of free radicals (Pintea et al., 2006). According to the study of Brzezniska-Slebodzinska et al. (1994), after calving such changes in MDA concentration are for short period and supply of high nutritive antioxidants can reduce the lipid peroxidation level very efficiently.

The overall mean value of the serum PON1 activity in $\mathrm{S}$ breed was found to be significantly higher in comparison to the HF breed in this research. The high serum PON1 concentration was observed in the mid lactation while lower values were detected in the as well as in the late lactation in both cow breeds. Similar results were obtained in the research of Kulka et al. (2016). During the peak lactation of different breeds, variation occurs in PON1 activities due to the reduced oxidative status. Such decline in PON1 activities after parturition continues as the lactation advances due to numerous alterations in the processes of oxidative status and of compensatory responses. Kulka et al. (2016) suggested that PON1 might be a valuable marker to diagnose antioxidative competency as well as to monitor the welfare of the cattle and the best indicator for finding the minimal redox state variations.

\section{Conclusions}

Based on the obtained results from our study it could be observed that the HF breed had a higher total milk production during all lactation periods with the lower fat and higher protein percentage compared to $\mathrm{S}$ cows breed. All lactating groups 
showed significantly high values of cholesterol, TOS and SOD at the peak lactation (HF2 and S2) stages. Decline from HF1 and S1 to HF3 to Sa3 was observed for the values of triglycerides and ALT, while the MDA increased during the same lactation stages in both breeds. The LDL and catalase showed an irregular pattern of variations in various lactation stages among all groups. Lactating HF breed showed significantly higher values of ALT and PON1, while values of HDL, TAS and TOS were higher in the $\mathrm{S}$ breed lactating group. By identifying these biomarkers showing signs of oxidative stress, it was concluded that metabolic efforts of cows at the peak lactation were influenced by the studied parameters. Disturbance in feed intake and rise in metabolic processes lift up oxidative stress in cows especially at the peak lactation and might be determined by monitoring blood alterations. Our results indicated that S cows was under higher oxidative stress during different physiological conditions when compared to HF cows. Finally, HF cows were considered more suitable for breeding due to their adaptations to the temperate environment. The results of the present study improved the knowledge of endocrine and metabolic variations in cows during various stages of lactation, and may be helpful to provide a latest strategy for cows farm management and productive performance improvement.

\section{Acknowledgements}

This work was supported by the Ministry of Education, Science and Technological Development of the Republic of Serbia under Grants III 46012 and TR 31095, and COST action under Grant CA17110.

\section{Upravljanje lipidnim profilom i oksidacijskim statusom kod krava holstein i simentaske pasmine tijekom laktacije}

\section{Sažetak}

Upravljanje i određivanje lipidnog profila krvi i oksidacijskog statusa vrlo je korisno sredstvo za dokazivanje utjecaja stranih kemijskih tvari na proizvodnju mliječnih krava. Istraživanje različitih biomarkera oksidativnog stresa povezanog s različitim problemima u proizvodnji mliječnih krava predstavlja vrlo važno pitanje. Cilj ovog rada je istražiti različite biološke markere krava holstein i simentalske pasmine, tijekom različitih faza laktacije. Ukupno 60 krava holstein i simentalske pasmine podijeljeno je u dva tretmana (HF i S) koji su dalje podijeljeni u tri skupine. Skupine svake pasmine krava bile su podijeljene u tri faze u ranoj laktaciji od 32-75 dana (HF1 i S1), maksimalna laktacija 80-165 dana (HF2 i S2) i niska laktacija od 175 dana nadalje (HF3 i S3). Tijekom pokusa utvrđena je ukupna proizvodnja mlijeka i postotak mliječne masti i proteina. Uzorci krvi su uzeti iz jugularne vene svake krave, dok serum je sakupljen bez antikoagulanta i pohranjen na $-20^{\circ} \mathrm{C}$ u malim alikvotima do daljnje analize. Serum je zatim analiziran na trigliceride, kolesterol, HDL, LDL, AST, ALT, GGT, ukupni antioksidacijski status (TAS), ukupni oksidacijski status (TOS), MDA, SOD, katalaze i paraoksonaze (PON1). Značajno $(\mathrm{P}<0,05)$ su se pokazale visoke vrijednosti kolesterola, TOS-a i SOD-a na vrhuncu laktacije kod svih krava. Postupno opadanje od rane laktacije do niske laktacije uočeno je u vrijednostima triglicerida, ALT, dok je MDA postupno rasla iz iste faze u svih krava, dok su LDL i katalaza pokazale nepravilan raspon varijacija u različitim fazama laktacije među svim skupinama. Holstein pasmina pokazala je značajno više vrijednosti ALT i PON1 (level of signifikance), dok su vrijednosti HDL, TAS i TOS bile niže u simentalskoj skupini. Pokazujući znakove oksidativnog stresa, zaključeno je da metabolički napori krava tijekom vrha laktacije utječu na istražene parametre. Poremećaj u unosu hrane i porast metaboličkih procesa podižu oksidativni stres kod krava, osobito tijekom vrha laktacije koji se može odrediti nadziranjem promjena u krvi. Rezultati istraživanja pokazali su da je krave holštajn pasmine bila pod većim oksidativnim stresom u različitim fazama laktacije u odnosu na krave simentaske pasmine. 
1. Ahmad, I., Lodhi, L.A, Qureshi, Z.I., Younis, M. (2004): Studies on blood glucose, total proteins, urea and cholesterol levels in cyclic, non-cyclic and endometritic crossbred cows. Pakistan Veterinary Journal 24, 92-94.

2. Barter, P. (2004): Metabolic abnormalities: high-density lipoproteins. Endocrinology and Metabolism Clinics of North America 33, 393-403. https://doi.org/10.1016/j.ecl.2004.03.006

3. Barter, P.J., Rye, K.A. (1996): High density lipoproteins and coronary heart disease. Atherosclerosis 121, 1-12. https://doi.org/10.1016/0021-9150(95)05675-0

4. Boonprong, S., Sribhen, C., Choothesa, A., Parvizi, N., Vajrabukka, C. (2007): Blood biochemical profiles of Thai indigenous and Simmental x Brahman crossbred cattle in the Central Thailand. Journal of veterinary medicine. Journal of Veterinary Medicine. Series A: physiology, pathology, clinical medicine 54 (2), 62-65. https://doi.org/10.1111/j.1439-0442.2007.00893.x

5. Brzezniska-Slebodzinska, E., Miller, J.K., Quigley, J.D., Moore, J.R., Madsen, F.C. (1994): Antioxidant status of dairy cows supplemented prepartum with vitamin $\mathrm{E}$ and selenium. Journal of Dairy Science 77, 3087-3095. https://doi.org/10.3168/jds.S0022-0302(94)77251-9

6. Castillo, C., Hernandez, J., Valverde, I., Pereira, V., Sotillo, J., Lopez-Alonso, M., Benedito, J. L. (2006): Plasma malonaldehyde (MDA) and total antioxidant status (TAS) during lactation in dairy cows. Research in Veterinary Science 80, 133-139. https://doi.org/10.1016/j.rvsc.2005.06.003

7. Celi, P., Gabai, G. (2015): Oxidant/Antioxidant balance in animal nutrition and health: The role of protein oxidation. Frontiers in Veterinary Science 2, 48-49. https://doi.org/10.3389/fvets.2015.00048

8. Chalmeh, A., Pourjafar, M., Nazifi, S., Momenifar, F., Mohamadi, M. (2015): Relationships among circulating metabolic biomarkers in healthy high-producing Holstein dairy cows in different physiological states. Bulgarian Journal of Veterinary Medicine 898, 1-11.

9. Davidson, M.H., Toth, P.P. (2007): High-density lipoprotein metabolism: potential therapeutic targets. American Journal of Cardiology 100, 32-40. https://doi.org/10.1016/j.amjcard.2007.08.011

10. Elazab, M.F.A. (2015): Evaluation of serum enzyme activities and protein fractions in Brucella-infected cows. Turkish Journal of Veterinary and Animal Sciences 39, 480484. https://doi.org/10.3906/vet-1504-31

11. Gardener, H., Morte, D.D., Mitchell, S.V., Elkind Sacco, L.R., Rundek, T. (2009): Lipids and carotid plaque in the Northern Manhattan Study (NOMAS). BMC Cardiovascular Disorders 9, 55 https://doi.org/10.1186/1471-2261-9-55

12. Goff, J.P., Horst, R.L. (1997): Effects of the addition of potassium or sodium, but not calcium, to Prepartum rations on milk fever in dairy cows. Journal of Dairy Science 80, 176-186. https://doi.org/10.3168/jds.S0022-0302(97)75925-3
13. Hagawane, S.D. Shinde, S.B., Rajguru, D.N. (2009): Haematological and blood biochemical profile in lactating buffaloes in and around Parbhani city. Veterinary World 2 (12), 467-469.

14. Hassan, M.M., Hoque, M.A., Islam, S., Khan, S.A., Hossain, M.B., Banu, Q. (2012): Efficacy of anthelmintics against parasitic infections and their treatment effect on the production and blood indices in Black Bengal goats in Bangladesh. Turkish Journal of Veterinary and Animal Sciences 36, 400-408.

15. Jezek, J., Klopcic, M., Klinkon, M. (2006): Influence of age on biochemical parameters in calves. Bulletin of the Veterinary Institute in Pulawy 50, 211-214.

16. Jóźwik, A., Strzałkowska, N., Bagnicka, E., Grzybek, W., Krzyżewski, J., Poławska, E., Kołataj, A., Horbańczuk, J.O. (2012): Relationship between milk yield, stage of lactation, and some blood serum metabolic parameters of dairy cows. Czech Journal of Animal Science 57 (8), 353-360. https://doi.org/10.17221/6270-CJAS

17. Koenyves, T., Zlatković, N., Memiši, N., Lukač, D., Puvača, N., Stojšin, M., Halasz, A., Miščević, B. (2017): Relationship of temperature-humidity index with milk production and feed intake of holstein-frisian cows in different year seasons. The Thai Journal of Veterinary Medicine 47 (1), 15-23.

18. Kostadinović, Lj., Popović, S., Puvača, N., Čabarkapa, I., Kormanjoš, Š., Lević, J. (2016): Influence of Artemisia absinthium essential oil on antioxidative system of broilers experimentally infected with Eimeria oocysts. Veterinarski Arhiv 86 (2), 253-264.

19. Krajnicakova, M.G., Kovac, G., Kostecky, M., Valocky, I., Maracek, I., Sutiakovai, I., Lenhardt, L. (2003): Selected clinical-biochemical parameters in the puerperal period of goats. Bulletin of the Veterinary Institute in Pulawy 47, 177-182.

20. Kulka, M., Kołodziejska-Lesisz, J., Kluciński, W. (2016): Serum paraoxonase1(PON1) activity and lipid metabolism parameters changes in different production cycle periods of Holstein Friesian, Polish Red and Norwegian breeds. Polish Journal of Veterinary Sciences 19 (1), 165-173. https://doi.org/10.1515/pjvs-2016-0021

21. Kurpińska, A.K., Jarosz, A., Ożgo, M., Skrzypczak, W.F. (2015): Changes in lipid metabolism during last month of pregnancy and first two months of lactation in primiparous cows - analysis of apolipoprotein expression pattern and changes in concentration of total cholesterol, HDL, LDL, triglycerides. Polish Journal of Veterinary Sciences 18 (2), 291-298. https://doi.org/10.1515/pjvs-2015-0038

22. Lai, M., Hyatt, B.J., Nasser, I., Cyrry, M., Fdhal, N.H.A. (2007): The clinical significant of persistently normal ALT in chronic hepatists B infection. Journal of Hepatology 47, 760-767. https://doi.org/10.1016/j.jhep.2007.07.022

23. Lim, J.S., Lee, D.H., Park, J.Y., Jin, S.H., Jacobs, D.R. (2007): A strong interaction between serum gammaglutamyltransferase and obesity on the risk of prevalent type 2 diabetes: results from the Third National Health and Nutrition Examination Survey. Clinical Chemistry 53 (6), 1092-1098. https://doi.org/10.1373/clinchem.2006.079814 
24. Ling, K., Jaakson, H., Samarutel, J., Leesame, A. (2003): Metabolic status and body condition score of Estonian Holstein cows and their relation to some fertility parameters. Revista de la Facultad de Medicina Veterinaria y de Zootecnia 24, 94-100.

25. Liu, P., He, B. X., Yang, X. L., Hou, X. L., Han, J. B., Han, Y. H., Nie, P., Deng, H. F., Du, X. H. (2012): Bioactivity evaluation of certain hepatic enzymes in blood plasma and milk of Holstein cows. Pakistan Veterinary Journal 32 (4), 601-604.

26. Milinković-Tur, S., Perić, V., Stojević, Z., Zdelar Tuk, M., Piršljin, J. (2005): Concentrations of total proteins and albumins, and AST, ALT and GGT activities in the blood plasma of mares during pregnancy and early lactation. Veterinarski Arhiv 75, 195-202.

27. Mohamed, G.A.E. (2014): Investigation of some enzymes level in blood and milk serum in two stages of milk yield dairy cows at Assiut city. Assiut Veterinary Medical Journal 61,144 .

28. Nemes, Z., Lukač, D., Petrović, M., Komlosi, I., Gaspardy, A. (2016): Estimation of nonadditive genetic influences on standard lactation production (305 days) in upgrading of Serbian-Fleckvieh to Holstein-Friesian cattle breed. Mljekarstvo 66 (4), 330-336. https://doi.org/10.15567/mljekarstvo.2016.0409

29. Obućinski, D., Prodanović, R., Ljubojević Pelić, D., Puvača, N. (2019): Improving competitiveness and sustainable approach to management in animal husbandry. Journal of Agronomy, Technology and Engineering Management 2 (1), 228-234.

30. Park, M.S., Yang, Y.X., Shinde, P.L., Choi, J.Y., Jo, J.K., Kim, J.S., Lohakare, J.D., Yang, B.K., Lee, J.K., Kwon, I.K., Chae, B.J. (2010): Effects of dietary glucose inclusion on reproductive performance, milk compositions and blood profiles in lactating sows. Journal of Animal Physiology and Animal Nutrition 94, 677-684. https://doi.org/10.1111/j.1439-0396.2009.00962.x

31. Pedernera, M., Celi, P., García, S. C., Salvin, H.E., Barchia, I., Fulkerson, W.J. (2010): Effect of diet, energy balance and milk production on oxidative stress in early-lactating dairy cows grazing pasture. The Veterinary Journal 186 (3), 352-357. https://doi.org/10.1016/j.tvjl.2009.09.003

32. Piccione, G., Messina, V., Marafioti, S., Casella, S., Giannetto, C., Fazio, F. (2012): Changes of some haematochemical parameters in dairy cows during late gestation, post partum, lactation and dry periods. Veterinarija Ir Zootechnika 58, 59-64.

33. Pintea, A., Daniela, Z., Pop, R. A., Sanda, A., Ervin, K. (2006): Antioxidant status in dairy cows during lactation. Bulletin of University of Agricultural Sciences and Veterinary Medicine 63, 130-135.

34. Popović, S., Kostadinović, Lj., Đuragić, O., Aćimović, M., Čabarkapa, I., Puvača, N., Ljubojević Pelić, D. (2018): Influence of medicinal plants mixtures (Artemisia absinthium, Thymus vulgaris, Menthae piperitae and Thymus serpyllum) in broilers nutrition on biochemical blood status. Journal of Agronomy, Technology and Engineering Management 1 (1), 91-98.
35. Popović, S., Kostadinović, Lj., Puvača, N., Kokić, B., Čabarkapa, I., Đuragić, O. (2017): Potential of wormwood (Artemisia absinthium) as a feed supplement in rabbit diet: effect on controlling rabbit coccidiosis, antioxidative systems and growth performance. Veterinarski Arhiv 87 (6), 769-782. https://doi.org/10.24099/vet.arhiv.160704a

36. Puvača, N., Čabarkapa, I., Bursić, V., Petrović, A., Aćimović, M. (2018): Antimicrobial, antioxidant and acaricidal properties of tea tree (Melaleuca alternifolia). Journal of Agronomy, Technology and Engineering Management 1 (1), 29-38.

37. Puvača, N., Kostadinović, Lj., Popović, S., Lević, J., Ljubojević, D., Tufarelli, V., Jovanović, R., Tasić, T., Ikonić, P., Lukač, D. (2016): Proximate composition, cholesterol concentration and lipid oxidation of meat from chickens fed dietary spice addition (Allium sativum, Piper nigrum, Capsicum annuum). Animal Production Science 56 (11), 1920-1927. https://doi.org/10.1071/AN15115

38. Ray, K.W., Flamm, S.L., Di Bisceglie, A.M., Bodenheimer, H.C. (2008): Serum activity of alanine aminotransferase (ALT) as an indicator of health and disease. Hepatology 47 , 1363-1370. https://doi.org/10.1002/hep.22109

39. Sattler, T., Furll, M. (2004): Creatine kinase and aspartate aminotransferase in cows as indicators for endometritis. Journal of veterinary medicine. A, Physiology, pathology, clinical medicine 51, 132-137. https://doi.org/10.1111/j.1439-0442.2004.00612.x

40. Sharma, N., Singh, N., Singh, O., Pandey, V., Verma, P. (2011): Oxidative stress and antioxidant status during transition period in dairy cows. Asian-Australasian Journal of Animal Sciences 24, 479-484. https://doi.org/10.5713/ajas.2011.10220

41. Stein, O., Stein, Y. (1999): Atheroprotective mechanisms of HDL. Atherosclerosis 144, 285-301. https://doi.org/10.1016/S0021-9150(99)00065-9

42. Subdhi, A.W., Davis, S.L., Kipp, R.W. (2001): Antioxidant status \& oxidative stress in elite alpine ski races. International Journal of Sport Nutrition and Exercise Metabolism 11 (1), 32-40. https://doi.org/10.1123/ijsnem.11.1.32

43. Upreti, K., Chaki, S. P., Misro, M. M. (2002): Evaluation of peroxidative stress and enzymatic antioxidant activity in liver and kidney during pregnancy and lactation in rats. Health and Population: Perspectives and Issues 25 (4), 177185. 